НАУКОВИЙ ВІСНИК

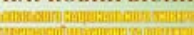

tanimail

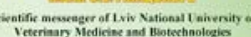

7

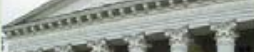

TIIT Toм 21 Nig 90

2019
Науковий вісник Львівського національного університету ветеринарної медицини та біотехнологій імені С.3. Гжицького. Серія: Сільськогосподарські науки

Scientific Messenger of Lviv National University of Veterinary Medicine and Biotechnologies. Series: Agricultural sciences

ISSN 2519-2698 print

https://nvlvet.com.ua/index.php/agriculture

doi: $10.32718 /$ nvlvet-a9010

\title{
Experience of certain countries in electronic and electric waste management
}

\author{
N. Kachmar, O. Mazurak, A. Dydiv, T. Bahday \\ Lviv National Agrarian University, Dubliany, Ukraine
}

Article info

Received 11.02.2019

Received in revised form 13.03 .2019

Accepted 14.03.2019

Lviv National Agrarian University, V. Velykyi, str., 1, Dubliany, Lviv region, Zhovkva district, 80381, Ukraine.

Tel: $+38-098-096-02-69$

E-mail: kachmarnatali@ukr.net
Kachmar, N., Mazurak, O., Dydiv, A., \& Bahday, T. (2019). Experience of certain countries in electronic and electric waste management. Scientific Messenger of Lviv National University of Veterinary Medicine and Biotechnologies. Series: Agricultural sciences, 21(90), 59-62. doi: $10.32718 /$ nvlvet-a9010

The paper present result of research concerning the problems of handling electronic and electrical waste that households produce at home and analysed the main problems associated with this issue in Ukraine and in the world. The object of the study was telephones (ukrainians use 53.6 million mobile communication devices), refrigerators, washing machines and TVs. The production of electrical and electronic equipment is one of the fastest growing global manufacturing activities. This development has resulted in an increase of waste electric and electronic equipment which constitute a risk to the environment and sustainable economic growth. Recycling of electronic and electrical waste is very expensive. There is a problem with electronic and electrical waste in Ukraine. To accumulate in the soil or to burn these waste is harmful. Every year on our planet about 50 million tons of electronic waste are generated. It was established that $53 \%$ of the interviewed students changed 1 phone in the last three years, $24 \%-2$ phones and $7 \%$ - more than 3. Students wanted a new phone. Most of the phones are at home, and the rest were given to their relatives or thrown into the trash. Ukrainians replace refrigerators, TVs and washing machines less often. Most Ukrainians change refrigerators. The largest amount of electronic waste is produced in Australia, New Zealand and Oceania (17.3 kg per inhabitant), in Europe - $16.6 \mathrm{~kg}$ per inhabitant and $11.6 \mathrm{~kg}$ waste per inhabitant of North and South America. In Japan, Norway, the Netherlands, Germany, Sweden and Poland, the process of disposal of used home appliances is well organized. However, economically developed countries utilize only part of the waste in their territory, while the rest are exported to landfills in Pakistan, Vietnam, Nigeria. The world's largest dump of electronic and electrical waste is in Ghana. To address potential environmental problems that could stem from improper management of WEEE, many countries and organizations have drafted national legislation to improve the reuse, recycling and other forms of material recovery from WEEE to reduce the amount and types of materials disposed in landfills.

Key words: electrical and electronic waste, recycling, experience of countries, dump.

\section{Досвід деяких країн у поводженні 3 електронними та електричними відходами}

\author{
Н.В. Качмар, О.Т. Мазурак, А.І. Дидів, Т.В. Багдай \\ Львівський національний аграрний університет, м. Дубляни, Україна
}

У статті наведені результати досліджень щуодо проблем поводження з електронними та електричними відходами, які населення продукує в домашніх умовах та проаналізовано основні проблеми, пов'язані з иим питанням в Україні та світі. Об єктом дослідження були телефони (украӥнці використовують 53,6 млн мобільних засобів зв 'язку), холодильники, пральні машини та телевізори. Виробництво електричного та електронного обладнання є однією з галузей, яка розвивається найшвидше. Інтенсивні темпи виробництва електрообладнання призвели до збільшення кількості їхніх відходів, які становлять ризик для навколишнього середовища та сталого економічного зростання. Процес утилізації даного виду відходів є досить дорогим. В Украӥні існує гостра проблема з електровідходами. Накопичувати в трунті чи спалювати використані електроприлади шкідливо. Щорічно на нашій планеті утворюється близько 50 млн тонн електронних відходів. Встановлено, щчо 53\% опитаних студентів за останні три роки змінили 1 телефон, 24\% - 2 телефони і 7\% - 3 і більше. Основною причиною зміни телефона було бажання володіти більш новою моделлю. Левова частка замінених телефонів зберігається вдома, а решта передані у користування іншим або просто викинуті у 
смітник. Великогабаритну побутову техніку українці замінюють рідше. Найчастіше украӥнські домогосподарства змінюють холодильники. Найбільша кількість досліджуваних відходів утворюється в Австралії, Новій Зеландії та країнах Океанї (17,3 кг на одного мешкания), у Свропі - 16,6 кг - на одного мешкания і 11,6 кг відходів на одного мешкания Північної та Південної Америки. Існує ряд країн, які бездоганно налагодили систему збирання електроприладів: Японія, Норвегія, Нідерланди, Німеччина, Швеція, Польща. Проте екологічно благополучні краӥни утилізують лише частину даних відходів на своїй території, а левову частку експортують на сміттєві полігони Пакистану, В'єтнаму, Нігеріі. Найбільше у світі звалище побутової техніки - на території столиці Гани. 3 метою вирішення ряду екологічних проблем, які виникають внаслідок неправильного поводження з досліджуваними відходами, багато краӥн та організаџій розробили національне законодавство, спрямоване на організацію процесу повторного використання, утилізації та вилучення придатного до використання матеріалу з електроприладів.

Ключові слова: електронні та електричні відходи, утилізація, досвід краӥн, сміттєзвалище.

\section{Ветуп}

Згідно з даними Міжнародної фінансової корпорації (IFC, Група Світового банку), Україна з 2012 року посідає перше місце у світі за кількістю відходів на душу населення - близько 300 кг за рік. Маючи у світі статус держави, значна частина жителів якої живе за межею бідності, ми продукуємо велику кількість електронних відходів. Деякі електроприлади справді вже стали непридатними для використання, а іноді ми просто піддаємося впливу реклами, яка пропагує нові моделі (Kachmar et al., 2018).

До відходів електронного та електричного обладнання належать: холодильники, плити, пральні машини, пилососи, праски, чайники, тостери, комп'ютери, принтери, копіри, телефони, телевізори, музичні центри, програвачі, музичні інструменти, лампи, дрилі, швейні машини, пили, газонокосарки, апарати для діалізу, аналізатори, кардіологічне обладнання, детектори диму, термостати, регулятори опалення, машини 3 видачі квитків, напоїв, банкомати.

Згідно з даними ООН щодо питань навколишнього середовища, щорічно на нашій планеті утворюється близько 50 млн тонн електронних відходів. Особливу увагу варто звернути на те, що темпи зростання їх утворення втричі швидші, у порівнянні з іншими видами відходів.

Достовірних офіційних даних щодо обсягів утворення, знешкодження та утилізації електричних та електронних відходів в Україні немає. В нашій державі ці відходи відносять до категорії ТПВ, а тому навіть їх приблизну кількість важко підрахувати. Якщо державні підприємства зобов'язані утилізувати свою оргтехніку, то приватні домогосподарства мають повну свободу дій, щодо поводження з використаною побутовою технікою (Klymenko et al., 2010; Natsionalna stratehiia upravlinnia vidkhodamy v Ukraini do 2030 roku).

Метою нашого дослідження було встановити частоту і причини зміни мобільних засобів зв'язку студентами ЛНАУ, проаналізувати подальшу долю використаних телефонів та іншої побутової техніки і показати на прикладі інших країн, які існують шляхи подолання даної проблеми.

\section{Матеріал і методи досліджень}

Для висвітлення обраної проблематики проводили аналіз літературних джерел та опитування студентів і викладачів ЛНАУ щодо поводження з використаними мобільними засобами зв'язку та великогабаритною побутовою технікою.

\section{Результати та їх обговорення}

На даний час українці використовують 53,6 млн мобільних засобів зв'язку, щорічно в Україну імпортують 300 тис. комп'ютерів та близько 300 млн батарейок. У 90-х роках існувала проблема: де купити ту чи іншу побутову техніку, а нині є актуальна проблема - куди ії подіти, оскільки налагоджене масове постачання даного продукту з країн Євросоюзу, що дає змогу українцям за помірні ціни оновити свої електроприлади. Значна кількість побутової техніки вже була у вжитку, а відповідно у нас вона теж вже довго не працюватиме. А це призводить до того, що люди все частіше будуть змушені купувати інші електротовари, а старі, за звичкою, просто викидати на смітник. Знову ж таки підтверджується факт, що екологічна безпека держави прямо залежить від економічного благополуччя населення.

Провівши опитування (скільки телефонів було змінено за останні три роки) між 100 студентами ЛНАУ, ми встановили, що 16\% опитаних не змінювали мобільних засобів зв'язку, 53\% змінили 1 телефон, $24 \%$ - 2 телефони і $7 \%-3$ та більше телефони. $45 \%$ студентів купували новий телефон не тому що він перестав працювати, а бажали мати новішу модель. Основна частина замінених телефонів (54\%) залишається лежати на поличках, але все ж таки настане час, коли їх просто викинуть у смітник, або вже це зробили. Частину телефонів (29\%) віддають у користування родичам, або (17\%) здають на запчастини чи викидають у смітник.

Дещо рідше змінюють українці великогабаритну побутову техніку. За результатами наших досліджень, які надають інформацію про періодичність зміни холодильників, телевізорів та пральних машин за останні 5 років, встановлено, що найчастіше українські домогосподарства змінюють холодильники, дещо рідше - телевізори і найдовше користуються пральними машинами. Загалом за п'ять років змінювали по одній одиниці техніки, а $25 \%$ опитаних не змінили жодного із вищезгаданих електроприладів. Практично у рівних співвідношеннях холодильники або віддають для вилучення 3 них робочих запчастин чи передають у користування іншим, або просто складують у підсобних приміщеннях. 80\% змінених пральних машин віддають на брухт. Старі телевізори здебільшого передають у користування іншим чи зберігають на горищі. Все-таки наше населення намагається не зали- 
шати прилади просто біля смітника. Проте дещо інша ситуація у пунктах прийому брухту. Потрібні частини вилучаються, а все інше потрапляе все ж таки на смітник.

Левова частка українських ТПВ, включаючи й відходи електричного та електронного обладнання, складується на 10000 га землі у вигляді полігонів та несанкціонованих звалищ, яких в Україні згідно з офіційними даними - 6700, а звалища у лісах та вздовж доріг ніхто й не обліковує. Проте, якщо говорити про поводження з досліджуваними відходами, то звалища, нехай і санкціоновані, абсолютно не вирішують даної проблеми (Halimova, 2016).

Значна частина жителів сільської місцевості взагалі позбавлена можливості централізованого збирання та вивезення відходів. Кількість продукованих українцями відходів з кожним роком лише зростає, а потужність існуючих кількох заводів, які утилізують відходи - зменшується.

Великою проблемою українців у питанні поводження з великогабаритними відходами $є$ відсутність будь-якої відповідальності за залишення побутової техніки біля смітників чи в іншому місці, яке зручне для людини. Мало хто переймається, якої шкоди завдає довкіллю залишений на вулиці телевізор чи холодильник. Сьогодні українці платять за утилізацію сміття в середньому одну гривню на одну людину щомісячно, а для вирішення проблеми потрібно платити в десять разів більше. Для українців це означає повне переосмислення свого ставлення до природи, формування екологічної свідомості у всіх прошарків населення. Адже прийняти, особливо сільським жителям, що необхідно платити за утилізацію сміття, яке вони безкоштовно вивозили на стихійні сміттєзвалища десятиліттями - це не справа короткого часу. Насамперед ми маємо усвідомити, що наші вчинки під гаслом “просто візьми і викинь” знижує якість нашого ж життя. Адже в грунт, воду, а потім через харчовий ланцюг - до організму людини потрапляють нові порції плюмбуму, ртуті, кадмію, хрому, полібромовані дифеніли та полібромовані дифенілові ефіри, полівінілхлорид, діоксини, які володіють потужною мутагенною дією на ДНК людини. Все більше приладів виготовляють $з$ пластику, який часто низької якості й особливо шкідливий. Науковцями встановлено, що у довкілля України щорічно внаслідок недбалого поводження 3 електронними відходами потрапляє: 40 кг ртуті, 160 кг кадмію, 400 т інших важких металів, 260 т сполук марганцю. Це страшна статистика, на яку ми поки що не зважаємо (Horobets, 2012).

Світовими лідерами 3 кількості генерування електронних відходів є: Австралія, Нова Зеландія та країни Океанії (17,3 кг - на одного мешканця), другу сходинку посідає Свропа (16,6 кг - на одного мешканця), 11,6 кг даних відходів на одного мешканця Північної та Південної Америки. У звіті Global E-waste Monitor 2017 Міжнародного союзу електрозв'язку ООН акцентується увага на тому, що за останні роки кількість електронних відходів стрімко зросла.

Викидаючи побутову техніку, ми не задумуємось: куди вона потрапить і якої шкоди завдасть. Яка ж ситуація в економічно розвинених країнах? На пер- ший погляд здається, що вони вже давно подолали і владнали цю проблему. Адже саме на їх прикладі ми хочемо вчитися, як це правильно робити. А чи завжди озвучують ці країни, що на їхній території утилізується лише частина даних відходів, а левова частка експортується на сміттєві полігони країн, які на фоні геополітичного простору безсилі перед передовими країнами світу. I такими країнами $є$ : Пакистан, В'єтнам, Нігерія. Проте найбільше у світі звалище побутової техніки - на території столиці Гани. Понад 3 тис. місцевих жителів змушені жити і дихати повітрям, яке перенасичене токсичними речовинами. Для значної частини жителів Аккре звалище Агбогблоші $є$ єдиним фінансовим джерелом, яке дозволяє їм хоч якось виживати. Правда в тому, що середній вік населення, яке ще з раннього дитинства займається розбиранням побутової техніки, щоб дістати цінні метали, становить в середньому 35 років. В економічно розвиненому світі люди такого віку вважаються ще досить молодими, а в Гані - вже закінчується життя. Невже гонитва за модою, бажання постійно підтверджувати свій суспільний статус і просто наша байдужість варта життів цих абсолютно беззахисних людей, що народилися на території бідної країни, яку заможні країни обрали для себе як місце куди їм дешевше відправити свої відходи, аніж утилізувати їх на своїй території. Часто екологічно зразкові країни експортують електроприлади як гуманітарну допомогу потребуючим країнам, але основна маса цієї техніки є лише відходами. Звалище, на яке щорічно звозять сотні мільйонів тонн побутової техніки, безперервно горить.

У деяких країнах світу ще з 90-х років практично бездоганно налагоджена система збирання електроприладів. Наприклад, у Норвегії, Нідерландах, Німеччині, Швеції у кожному місті є так званий полігон, куди власник особисто, або за окрему плату спеціальна служба відвозить електроприлади. Якщо прилади у робочому стані, то, наприклад у Німеччині, їх просто залишають на вулиці, звідки вони часто і потрапляють до України. Японці покривають не лише витрати на утилізацію, а навіть витрати на пальне, щоб відповідна служба відвезла використану побутову техніку до пункту утилізації. Оплата проводиться заздалегідь, а талончик наклеюється на техніку. Існує і практика повернення використаної побутової техніки у магазин, де вона була придбана, але, звісно, оплативши процес утилізації. В Лондоні негабаритні відходи можна залишити у контейнерах, яких є достатня кількість. В Австралії електроприлади (на даний час експлуатуються понад 9,5 млн комп'ютерів, 5 млн принтерів, 2 млн сканерів) забирають муніципальні служби безпосередньо від житлового будинку, та лише у визначені дні. Залишивши стару електротехніку біля смітника, житель Польщі зобов'язаний буде сплатити штраф у розмірі до 1,5 тис. дол. I це діє. У Польщі також існують спеціальні пункти прийому використаної техніки, а для людей, які мають намір придбати нову техніку дозволяється стару залишити безпосередньо в магазині. Послуги утилізації електроприладів у Польщі можуть бути як платними, так і безкоштовними, це залежить від типу організації, яка забезпечує 
цей процес. Існує безкоштовне таксі у Білорусії, яке відвезе вашу техніку у пункт утилізації.

У Швеції функціонує єдиний у світі торговий центр, де продають лише товари, що вже були раніше у вжитку. Пункт, куди звозять використані речі, міститься безпосередньо в торговому центрі. Частину речей, які полагодили, продають, а решту відправляють на утилізацію.

Відомі у всьому світі компанії-виробники побутової техніки, Dell, Sony, Samsung, Nokia, Siemens/ Fujitsu, Canon самі займаються питаннями утилізації використаної техніки. Усі витрати на процес покриваються згаданими компаніями.

Загалом у світі існує практика зменшення податків для компаній, які допомагають державі в організації процесу утилізації даних відходів. Часто система працює виключно на особистій відповідальності громадян.

Складається враження, що у питанні поводження 3 використаною побутовою технікою Україну випередили всі цивілізовані країни.

Для вирішення даної проблеми насамперед необхідно організувати процес збирання даного виду відходів, підготувати їх до знешкодження, а у випадку України - побудувати заводи, які б усі ці усно заявлені ідеї могли реалізувати на практиці. В даний час на території України діє 15 підприємств, які переробляють електронні відходи. Це недостатня кількість. Проблема має вирішуватися на рівні держави, а не на рівні амбіцій і волонтерства окремих осіб. Масштаби проблеми надто великі, щоби бути вирішеними силами лише населення без участі керівного апарату держави. Вкладені в будівництво заводів кошти з часом будуть приносити не лише економічний прибуток, а й дадуть можливість врятувати нашу планету. Екологічне благополуччя вищезгаданим країнам обійшлося досить дорого, але це кошти, які вони інвестували у поліпшення якості життя, й це безцінні капіталовкладення (Horobets, 2012; Natsionalna stratehiia upravlinnia vidkhodamy v Ukraini do 2030 roku).

Надіємось, що ситуація в Україні поліпшиться ще й тому, що відповідно до Угоди про асоціацію з Свропейським Союзом, наша держава має зобов'язання протягом найближчих років впорядкувати поводження $з$ відходами та привести законодавство у відповідність до європейських вимог.

\section{Висновки}

Основною причиною пришвидшення процесу нагромадження електронних та електричних відходів на території України є спрощена процедура імпорту вже користованої техніки з країн Свросоюзу.

Встановлено, що часто студенти купували новий телефон не тому, що він перестав працювати, а бажаючи мати новішу модель. Така ж ситуація і $з$ телевізорами. Холодильники i пральні машини зазвичай замінюють, коли вони виходять із ладу.

Прикладом для наслідування у питаннях організації процесу збирання електричних та електронних відходів можуть бути Норвегія, Нідерланди, Німеччина, Швеція, Японія, Польща, але збирання не завжди гарантує утилізацію.

Найбільше згадуваних відходів передовими країнами світу експортується на сміттєві полігони Гани, Пакистану, В'єтнаму та Нігерії.

Вирішення даної проблеми для України можливе лише у разі чіткого дотримання законодавства, будівництва заводів, які б забезпечували утилізацію ТПВ та формування екологічної свідомості й екологічної культури у всіх верств населення.

\section{References}

Halimova, M. (2016). Vidkhody v Ukraini: aktualna problema, shcho obernulasia trahediieiu. Ekolohichnyi Visnyk, 3, 2-5 (in Ukrainian).

Horobets, O.V. (2012). Orhanizatsiino-ekonomichne zabezpechennia protsesiv povodzhennia z tverdymy pobutovymy vidkhodamy u silskii mistsevosti Zhytomyrskoi oblasti. Visnyk Zhytomyrskoho natsionalnoho ahroekolohich-noho universytetu. Zhytomyr: ZhNAEU, 2(2), 364-370. http://ir.znau.edu.ua/handle/ 123456789/1898 (in Ukrainian).

Kachmar, N.V., Bahdai, T.V., \& Dydiv, A.I. (2018). Dosvid deiakykh krain u povodzhenni z plastykovym smittiam. Teoriia i praktyka rozvytku ahropromyslovoho kompleksu ta silskykh terytorii: materialy XIX Mizhnarodnoho nauk.-prakt. forumu (m. Dubliany, 19-21veresnia 2018 r.). Lviv: Liha-Pres, 75-78 (in Ukrainian).

Klymenko, M.O., Pylypenko, Yu.V., \& Moroz, O.S. (2010). Ekolohiia miskykh system: pidruch. Kherson: Oldy-plius (in Ukrainian).

Natsionalna stratehiia upravlinnia vidkhodamy v Ukraini do 2030 roku. Elektronnyi resurs. https://eco.kiev.ua/assets/files/Osnovna-chastina.pdf (in Ukrainian). 